DOI 10.31558/2307-2318.2021.4.18

УДК 338.432

JEL: E22, E23, F01

Кукель Г. С.

к. е. н., кафедра міжнародних економічних відносин Донецький національний університет імені Василя Стуса

ORCID ID: 0000-0001-7699-5997

h.kukel@donnu.edu.ua

Братчук У. П.

аспірант, кафедра міжнародних економічних відносин Донецький національний університет імені Василя Стуса

ORCID ID: 0000-0003-0022-1543

u.bratchuk@donnu.edu.ua

Штефан Л. Б.

к.е.н., доцент, доцент кафедри фінансів банківської справи та страхування

Вінницький навчально-науковий інститут економіки

Західноукраїнського національного університету

ORCID: https://orcid.org/0000-0002-3428-5193

\title{
ПІДВИЩЕННЯ КОНКУРЕНТОЗДАТНОСТІ АГРАРНОГО ВИРОБНИЦТВА В УМОВАХ ГЛОБАЛІЗАЦЇ̈
}

У статті розкрито сутність та особливості процесів глобалізаиії, відображено вилив цих процесів на розвиток вітчизняного сільського господарства. Водночас визначено потенційні та пріоритетні напрями підвищення конкурентоздатності аграрного виробництва в сучасних умовах. Висвітлено вплив тенденцій на глобальних фінансових $і$ ринках товарів та послуг на стратегію підприємств аграрного сектору. Охарактеризовано сучасний стан та умови господарювання аграрних підприємств. Визначено основні важелі забезпечення конкурентоспроможності аграрного виробництва. Здійснено аналіз, оиінку й діагностику сучасного стану та перспектив національного виробництва сільськогосподарської продукиії в глобалізованому світі, обтрунтувано засоби удосконалення механізмів і стратегій управління конкурентоспроможним розвитком аграрного сектору, концептуальні засади його державного регулювання. Розкрито роль та значення державної підтримки аграрних підприємств у гарантуванні продовольчої безпеки, забезпеченні конкурентоспроможності та економічної стійкості аграрних підприємств з урахуванням їх спеціалізації.

Ключові слова: аграрні підприємства, конкурентоздатність, економічне зростання, інтеграція, конкурентоспроможний розвиток, інноваџї, глобалізація, інвестиції.

Постановка проблеми. Аграрний сектор економіки України на сучасному етапі розвитку можна охарактеризувати суттєвими системними особливостями i структурними зрушеннями, що зумовлюються процесами глобалізації та євроінтеграції. Мова йде про капіталізацію та концентрацію аграрного виробництва в короткі терміни, 
стрімкий вихід України на світовий продовольчий ринок, модернізацію основних засобів та технологій, оптимізацію зайнятості в АПК. Але зазначені позитивні зрушення супроводжуються погіршенням загального стану агроландшафтів та зниженням природної продуктивності земель, неефективною спеціалізацією виробництва та недостатнім державним контролем за його веденням, також актуальними $є$ проблеми слабкої організації розвитку сільських територій, недостатньої диверсифікації видів діяльності, безробіття більшості сільського населення. Не набула завершального етапу земельна реформа, подальшого розвитку потребують страховий і фондовий ринки, фінансово-кредитний механізм господарювання, вимагає вдосконалення державна соціальна політика.

Глобалізація світової економіки, що $є$ об'єктивним процесом, робить визначальний вплив на розвиток всіх країн. Основу цього процесу утворює «економіка знань» - інновації, нові технології, високоосвічений, кваліфікований персонал. В умовах сьогодення конкурентоспроможною може бути тільки та національна економіка, що найефективніше використовує можливості глобалізації. Аграрний сектор, як і інші сфери економіки, знаходиться під впливом глобалізації, міжнародних потоків капіталу та інвестицій, транснаціональних корпорацій [3, с. 129].

Перед нашою державою й вітчизняним аграрним бізнесом постало завдання розв'язання важливої проблеми, що пов'язана з вибором та реалізацією ефективних шляхів розвитку в нових геополітичних умовах, а наслідки впливу глобалізації стають дедалі відчутнішими. Отже, йдеться про необхідність розробки відповідних конкурентних стратегій, інструментів та механізмів, що й визначає актуальність даної статті.

Аналіз останніх досліджень і публікацій. Питання управління конкурентоспроможністю в умовах глобалізації знайшли своє відображення в працях закордонних учених: Ф. Котлера, Г. Мінцберга, М. Портера, Ф. Тейлора, А. Сміта, Р. Уотермена, Е. Чемберлена, Й. Шумпетера, а також вітчизняних науковців: Л.Л. Антонюк, П.Ю. Бєлєнького, А.Е. Воронкова, Ю.Б. Іванова, Г.В. Кривенка, І.О. Піддубного, О.Б. Чернеги, В.Г. Шинкаренко та ін.

Мета цієї статті - виявлення та наукове обгрунтування внутрішніх і зовнішніх факторів та умов забезпечення конкурентоспроможності аграрного виробництва. У своїй інтерпретації основних напрямків, ці фактори і умови повинні бути придатними для сучасного практичного використання 3 виробництва конкурентоспроможної сільськогосподарської продукції, сировини і продовольства.

Виклад основного матеріалу дослідження. Слід зазначити, що 2020 рік був одним із найскладніших за останні роки для вітчизняного агропромислового комплексу, що зумовлено, насамперед, вкрай несприятливими погодними умовами, загальносвітовою тенденцією до значного здорожчання всіх складових виробництва, передусім енергетичної та пандемією COVID-19.

Україна опустилася на одну позицію за індексом конкурентоспроможності та стала 55 з 63 країн, і залишається найменш конкурентоздатною в регіоні Західної та Східної Європи. Про це йдеться в рейтингу індексу конкурентоздатності країн 2020 року, опублікованому Міжнародним інститутом управління розвитком.

Впродовж 2020 року сільське господарство функціонувало в умовах подолання викликів, таких як природні катаклізми та діяльність при карантинних обмеженнях як в середині країни (внутрішній ринок), так в країнах-партнерах (зовнішній ринок). Певним чином вплив пандемічного фактору відобразився на тваринництві в незначний 
частині залежності їі діяльності від зовнішнього попиту, який в більшості країн партнерів був суттєво нижчим за звичайний.

В цілому попит на продукти сільського господарства (у т.ч. внутрішній) підтримували діяльність галузі і агробізнес міг скористатися програмами підтримки від Уряду (зокрема, «Кредитні канікули», «Податкові преференції» та «Підтримка малого і середнього бізнесу»), які певною мірою дозволяли зняти фінансове навантаження на підприємців у період карантинних обмежень. Крім того, на противагу 2019 р. сільськогосподарські виробники у 2020р. функціонували в умовах стабільної державної підтримки АПК, виплаченої майже в повному обсязі, запланованому у бюджеті 2020p., що у складних умовах забезпечувало фінансову стабільність у сільському господарстві. За даними Мінекономіки у 2020p. було збережено аграрну підтримку і виплачено аграріям усі 4 млрд грн. (у 2019p. сплачено 4,8 млрд. грн з передбачених 5,9 млрд грн).

В таких умовах, ключову роль у сільському господарстві зіграло значне погіршення погодних умов, що суттєво вплинуло на результати рослинництва, яке маже повністю і сформувало негативний внесок у падінні сільськогосподарського виробництва.Відтак, за підсумком 2020p., на противагу попереднім двом рокам, обсяги виробництва с/Г продукції значно скоротилися - на 11,5\%.

Таблиця 1 Обсяги виробництва сільськогосподарської продукції 2018-2020 рр.

\begin{tabular}{|l|c|c|c|c|c|c|}
\hline \multirow{2}{*}{$\begin{array}{l}\text { Ключові } \\
\text { показники }\end{array}$} & \multicolumn{3}{|c|}{ Річна зміна, \% } & \multicolumn{3}{c|}{ Місячна зміна, \% } \\
\cline { 2 - 7 } & 2018 & 2019 & 2020 & $\begin{array}{c}\text { Грудень } \\
2018\end{array}$ & $\begin{array}{c}\text { Грудень } \\
2019\end{array}$ & $\begin{array}{c}\text { Грудень } \\
2020\end{array}$ \\
\hline $\begin{array}{l}\text { Сільське } \\
\text { господарство }\end{array}$ & 8,2 & 1,4 & $-11,5$ & 7,4 & $-15,2$ & 26,0 \\
\hline Рослинництво & 10,2 & 1,8 & $-13,9$ & - & - & - \\
\hline Тваринництво & 1,2 & 0,2 & $-2,6$ & - & - & - \\
\hline
\end{tabular}

Джерело: Держстат, розрахунки Мінекономіки

За підсумком 2020p. обсяги виробництва рослинницької продукції скоротилися на 13,9\%. Дана галузь одна 3 небагатьох, яка не відчула негативного впливу карантинних обмежень. А як і в попередніх роках переважно залежала від погодних кліматичних умов, що у 2020p. в основному характеризувалися як нестабільні і складні та мали суттєвий негативний вплив (тепла і малосніжна зима, низькі запаси вологи в грунті, заморозки у весняний період та засуха в період вегетації в окремих регіонах) під час перезимівлі озимих культур, а також вегетації та дозрівання основних с/г культур. Це відповідно позначилося на зниженні врожайності більшості с/г культур порівняно 3 минулим роком, зокрема: зернових культур - зменшення урожайності на $14,7 \%$, обсягів врожаю - на 17,6\% станом на 01.12.2020, соняшнику - на 20,8\% та 14,6\% відповідно, сої - на $12,9 \%$ та $32,9 \%$, буряка цукрового - на $6 \%$ та 29,6\%, овочів відкритого грунту на $2,9 \%$ та $0,8 \%$, а також культур плодоягідних - врожай "мінус" 8,3\% станом на 01.12.2020 [1].

Незважаючи на скорочення, отримані обсяги врожаю забезпечили продовольчу безпеку країни та дозволили формувати активну зовнішньоекономічну діяльність сільськогосподарською продукцією.

За даними Мінекономіки у 2020/2021 р. експорт зернових культур становитиме майже 48 млн т (у 2019/2020 р. на зовнішні ринки було поставлено рекордні 57,2 млн т), станом на 15.01.2021 було експортовано 27,3 млн т зернових та зернобобових культур. За даними ДМС у 2020 р. питома вага зернових культур у експорті країни у 
вартісному вимірі становить 19,1\% (19,2\% у 2019p.). В даних умовах Україна продовжувала займати високі показники у рейтингу світового виробництва зернових культур та соняшнику.За підсумками 2020p. у виробництві тваринницької продукції спостерігалося скорочення обсягів виробництва на 2,6\% і на противагу рослинництву найбільший негативний вплив на галузь відбувся через зниження зовнішнього попиту на продукцію птахівництва, яке поєдналося 3 впливом факторів, які формувалися у попередніх періодах, а саме: високі фінансові затрати на вирощування поголів'я ВРХ та зростання конкуренції на внутрішньому ринку з імпортною молочною продукцією, яка в переважній більшості субсидіюється іншими країнами (за даними ДМС у 2020 р. імпорт молочної продукції (гр.401-406)) зріс у 2,1 рази, низькі закупівельні ціни на молоко у господарств населення (за даними Держстату за 10 міс. 2020 р. закупівельні ціни на молоко у господарств населення порівняно з підприємствами нижчі на 22,2\%) [5].

Як наслідок, виробництво молока скоротилося на 4,2\%. У свою чергу, у 2020p. карантинні обмеження у країнах торгових партнерах перманентно негативно впливали на попит на вітчизняну продукцію птахівництва. Так, виробництво яєць скоротилося на $2,9 \%$, у т.ч. на тлі зменшення поголів'я птиці з урахуванням впливу закриття окремих птахофабрик на тлі зниження рентабельності вирощування птиці. Крім іншого мав місце і певний вплив активізації антимонопольних процесів через порушення законодавства про захист економічної конкуренції. За даними ДМС у 2020p. експорт яєць (гр.407-408)) скоротився на 20,5\%. Станом на 01.01.2021.поголів'я ВРХ скоротилося на 6,2\%, птиці - скоротилося на 9,3\%, а свиней - зросло на 2\%. У 2020p. обсяги реалізації на забій с/г тварин (у живій масі) зменшились на 1,1\%.

Перетворення агропромислового комплексу на високоефективний, конкурентоспроможний сектор економіки держави - це, без перебільшення, питання здатності агропромислового комплексу країни інтегруватися у світовий аграрний ринок.

Конкурентоспроможність галузі є багатогранним поняттям, яке характеризує іiі спроможність конкурувати на внутрішньому та зовнішніх ринках i вимірюється ступенем присутності на них вітчизняної продукції. Два основних взаємозв'язаних чинники, що визначають конкурентоспроможність - це собівартість виробництва та ціни реалізації, що значною мірою визначаються якістю сільськогосподарської продукції та продовольства.

Основним важелем забезпечення конкурентоспроможності $\epsilon$ ефективність господарської діяльності.

3 метою реальної оцінки стану аграрного сектору економіки та його готовності до вищезазначеної інтеграції міністерством спільно з науковцями здійснено оцінку конкурентоспроможності вітчизняних сільськогосподарських підприємств.

Результати досліджень показують наявність трьох груп продукції за рівнем конкурентоспроможності:

група конкурентоспроможної продукиії (насіння соняшнику і продукти його переробки, продовольче та фуражне зерно й продукти його переробки, насіння ріпаку і сої та продукти їх переробки);

група продукиї перспективної конкурентоспроможності (м'ясо птиці, овочі, яйця, молоко та молокопродукти, свинина, картопля, мед);

група продукиії з низькою перспективою створення конкурентоспроможності (яловичина, цукор, льон, фрукти, виноград).

Для кожної групи передбачена певна стратегія дій. 
Для першої групи: утримання існуючих позицій та підвищення конкурентоспроможності за рахунок інтенсифікації виробництва і поглиблення рівня переробки. Умовою інтенсифікації є безумовне виконання технологій виробництва та переоснащення основних фондів галузі. Для виконання першої умови необхідно в 1,6-2 рази збільшити обсяги обігових коштів, які щорічно залучаються у виробництво, а другої - залучення інвестицій.

Для другої групи: $з$ метою використання потенціалу галузей, що ввійшли до даної групи, необхідно створити умови для швидкого зростання конкурентоспроможності продукції за рахунок залучення інвестицій та відповідної державної підтримки.

Важливим також є використання внутрішніх резервів, наприклад ефекту від вертикальної інтеграції, що може забезпечити зниження трансакційних втрат i кумулятивний ефект від різних етапів господарської діяльності.

Для третьої групи: визначення соціально-значущих галузей, відносно яких, у випадку неможливості або неефективності залучення необхідних інвестиційних ресурсів за рахунок стабільності створених державою умов, повинно бути прийнято рішення по реструктуризації галузі.

Нині макроекономічну ситуацію в сільськогосподарських підприємствах товарно-ринкового спрямування можна в цілому оцінити як позитивну, а їхню конкуренто-спроможність за результатами попереднього року - достатньо високою.

Зазначимо, що в умовах експортно-орієнтованого аграрного виробництва його ефективність на внутрішньому ринку цілком залежить від ситуації на світовому ринку. Слід чітко усвідомити, що світова економіка вступила в нову епоху надвисоких цін на нафту, а це є основним викликом для країн нетто-імпортерів, до яких належить i Україна.

Тому серед причин структурного плану, які стосуються основних чинників здорожчання сільськогосподарської продукції, слід передусім назвати подорожчання нафти та нафтопродуктів, що зумовлює зростання витрат сільськогосподарського виробництва. Так, за деякими даними, рекордна динаміка нафтових цін призвела до того, що вартість добрив і перевезень великих партій товарів зросла в 2020 році на 80 \% порівняно з попереднім роком.

Очевидно, що ця тенденція вже присутня в Україні, а в подальшому роль «нафто-вого» чинника зростатиме.

Подорожчання нафти та нафтопродуктів призводить до зростання попиту на біопаливо й, відповідно, на сировину для його виробництва. За даними ФАО, очікується, що цей процес стосуватиметься передусім зернових, насіння олійних культур, цукру і рослинних олій; що протягом наступного десятиріччя значні обсяги кукурудзи в США, пшениці та насіння ріпаку в Європі, цукру в Бразилії

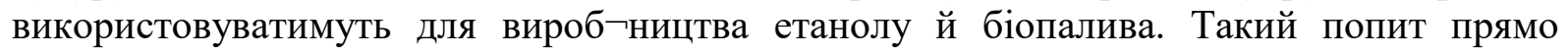
впливатиме на ціни на перелічені куль $\neg$ тури та опосередковано - через ціни на фураж на ціни продукції тваринництва і птахівництва.

Окремо слід зазначити, що високі ціни на нафту також зумовили появу спеціальної політики стимулювання виробництва біопалива.

Реакція з боку виробників на досить сильні фінансові стимули не забарилася. За даними Світового банку, сьогодні в США 20 \% кукурудзи використовується для виробництва біопалива, тоді як в Свросоюзі на ці цілі йде 68 \% рослинної олії.

Для України це означає нові можливості для розвитку сільськогосподарського виробництва, в тому числі за рахунок залучення іноземного капіталу. 
Серед структурних чинників слід також назвати різке зростання попиту на продукти харчування з боку таких країн, як Китай та Індія, особливо на м'ясо і молоко. Це, в свою чергу, призводить до зростання ціни на зерно для відгодівлі худоби.

За прогнозами ФАО, протягом наступних десяти років ціни на продукти харчування якщо й не зростатимуть, все одно залишатимуться на досить високому рівні. Тому збільшення попиту й цін на сільськогосподарські продукти через певний період часу зумовить зростання пропозиції. Це означає, що в середньо- i довгостроковій перспективі Україна, як й інші виробники продукції сільського господарства, може та повинна скористатися такою ситуацією, аби найповніше реалізувати свій аграрний потенціал, щоб не лише задовольнити власні потреби, а й значно наростити обсяги експорту сільськогосподарської продукції.

Водночас, у структурі вітчизняного експорту повинна дедалі менше домінувати сировина, а переважати - продукти їі переробки.

Зупинимося на окремих напрямах підвищення конкурентоспроможності вітчизняного сільськогосподарського виробництва.

Ринок зернових. Якість зерна, ефективна робота на зовнішніх ринках i мінімізація маржі та інфраструктурних витрат на внутрішньому ринку повинні дати змогу виробникам одержувати не менше 80 \% від світової ціни.

Ринок продукції олійно-жирового комплексу. Необхідно й надалі підтримувати тенденції останніх років щодо збільшення частки ріпаку і сої в структурі виробництва олійних культур та зменшення площ під соняшником до науково обгрунтованих обсягів, підвищувати його врожайність. Це дасть змогу вже через 3-5 років збільшити в 1,5 рази виробництво олійних культур, що в свою чергу позитивно вплине на прибутковість галузі. Увесь обсяг виробленого насіння повинен перероблятися в Україні, оскільки наявні потужності переробних підприємств дають змогу це зробити.

Цукробуряковий комплекс. Нині обсяги виробництва цукру в державі, по суті, досягли свого критично - низького рівня. Основною причиною такого стану виявилася неконкурентосроможність галузі. При цьому досвід окремих підприємств, реконструйованих з урахуванням новітніх технологій, та практика створення потужних холдингів (Астарта, Укрпромінвест) вказують на нагальну потребу й можливість реформування галузі.

У цьому контексті слід зауважити, що перспективу неконкурентоспроможних підприємств галузі вбачаємо в їх перепрофілюванні на виробництво біоетанолу.

Ринок тваринницької продукції.

У галузі тваринництва тривожним $є$ той факт, що три чверті продукції надходить від господарств населення, що практично позбавляє цю галузь перспектив конкурентоспроможності.

Разом із тим відновлюються позитивні тенденції в свинарстві, а також продовжено технологічний прорив у галузі птахівництва, де маємо виробництво продукції на рівні світових стандартів, яка $є$ конкурентоспроможною як за ціною, так і за якістю. Це є показовим щодо використання ефекту вертикальної інтеграції, коли результати господарювання примножуються за рахунок переробки i маркетингу продукції й повинно стати прикладом для інших напрямів виробництва продукції тваринництва.

Актуальним $є$ питання підвищення ефективності від реалізації цільових галузевих програм і наявного рівня державної підтримки тваринницької галузі. 
I Зокрема, слід сконцентрувати увагу на збільшені використання зерна для нарощування виробництва продукції тваринництва та іiі подальшого експорту як це робиться в більшості європейських держав.

Підсумовуючи вищезазначене, слід акцентувати увагу на тому, що існує лише один основний чинник, який може забезпечити успіх у конкурентній боротьбі щодо ціни та якості - це новітні й ресурсозберігаючі технології. Маємо визнати, що Україна порівняно 3 розвинутими країнами програє по головних показниках ефективності виробництва: продуктивності праці, техніко-технологічній забезпеченості, енергомісткості, врожайності сільськогосподарських культур, продуктивності худоби.

В усіх без винятку галузях слід вести виробництво на основі науково обгрунтованих, економічно виважених систем i технологій, які максимально враховують природно-кліматичні умови, потенціал України в світовій економіці та кращий світовий досвід.

3 огляду на це, земельний ринок може стати чи не основним джерелом залучення фінансових ресурсів в агропромислове виробництво, але для цього необхідно вже найближчим часом напрацювати відповідний інструментарій.

Мабуть, доцільно вести мову про активізацію роботи в цьому напрямі державної іпотечної установи, що, з одного боку, давало б гарантії фінустановам щодо повернення кредитних ресурсів і поліпшувало б умови кредитування для аграріїв, а 3 іншого - дало б можливість державі ефективно впливати на рух земель сільськогосподарського призначення.

На часі також опрацювання механізмів довгострокового пільгового кредитування

аграріїв, що орендують земельні ділянки не менше 3-5 років, з метою викупу таких земельних ділянок.

Безумовно, необхідно прискорити прийняття й інших законодавчих актів, що гарантуватимуть створення цивілізованої інфраструктури земельного ринку.

Пріоритетним напрямом підвищення конкурентоспроможності є удосконалення фінансово-економічних умов господарювання сільгосппідприємств, зокрема формування доступу до фінансових ресурсів, системи державної підтримки та удосконалення умов оподаткування.

Окремої уваги потребує питання формування інфраструктури ринків аграрної продукції, на яких базується система організованого ринку, що суттєво впливає на конкурентоспроможність вітчизняного аграрного сектора.

Однак ще залишаються невирішеними питання скоординованих дій усіх учасників аграрного ринку. Все ще актуальні питання об'єктивного розрахунку ринкових параметрів, удосконалення роботи державних агентів i, можливо, удосконалення самого ринкового інструментарію, який до останнього часу характеризувався певним суб'єктивізмом.

Слід також наголосити на необхідності концентрації зусиль аграрної науки в цілому і зокрема її економічному загону на пріоритетних напрямах.

Вітчизняна наука повинна зробити крок уперед - сьогодні вже мало напрацювати технологію - треба на конкретно напрацьованих моделях переконати товаровиробників і їх конкурентоспроможності. Необхідно на практиці показувати комерційну успішність технологій (як це роблять закордонні постачальники техніки, обладнання, насіння або агрохіміі).

Потребує посилення практичний аспект роботи аграрних економістів. Світова наука пішла в цьому плані набагато далі - як у багатьох країнах постійно роблять 
прикладні розрахунки щодо впливу на ефективність діяльності сільгосппідприємств тих чи інших кроків аграрної політики. Наприклад, чи сприяє надання дотацій на закупівлю міндобрив зростанню ефективності, які варіанти тваринницьких дотацій $є$ найбільш дієвими тощо.

Наступний.крок для аграріїв - пошук фінансових ресурсів для впровадження техᄀнологій, закупівлі техніки й обладнання. I тут також необхідно запропонувати нововведення, здатні полегшити прогрес тих підприємств, які потенційно спроможні його досягти.

Черговий крок - формування ринків. Вважаємо, що треба відійти від традиції ототожнювати ринки лише з кооперативом або агроторговим домом - на часі докорінне удосконалення ринкового інструментарію. Форвардна й ф'ючерсна торгівля дала б можливість i аграріям, i державі «бачити» ринок на перспективу, раціонально планувати структуру посівів, прогнозувати доходи від реалізації. В результаті управлінці мають можливість приймати виважені та обгрунтовані рішення, а поки що працюємо значною мірою інтуїтивно. Отже, аграрії чекають від аграрної науки нових напрацювань для підвищення конкурентоспроможності агропромислового виробництва.

Питання підвищення конкурентоспроможності сільського господарства в Україні, насамперед, тісно пов'язані з необхідністю диверсифікації інституційного розвитку багатоукладної економіки, оскільки близько половини продукції виробляється в низькотоварному секторі особистих господарств населення. У цьому зв'язку сукупна товарність по аграрних господарствах всіх категорій не перевищує i половини виробництва сільськогосподарської продукції.

В умовах сучасної індустріальної економіки для аграріїв це нонсенс, якщо вести мову про конкурентоспроможність українського продовольства на міжнародному ринку. Низьковиробнича ручна праця в особистих селянських господарствах різко підвищує в цілому трудомісткість сільського господарства i знижує рівень продуктивності праці, цим самим стримує рівень зайнятості населення і сприяє обезлюдненню села. Рівень зайнятості сільського населення в 2019 р. становив 62,2\%, міського - 68,2\%. Загальна кількість зайнятих у сільському господарстві - 2,9 млн. осіб. Рівень безробіття серед сільського населення України становить 10,9\%, серед міського - 9\%. За офіційними даними, кількість трудових мігрантів становить близько 7\% від соціально активного населення; за неофіційними оцінками, кількість трудових мігрантів із села сягає 2 млн. осіб. Якщо кількість активного сільського населення - 5,6 млн. осіб, то 2 млн. трудових мігрантів - це багато. Такого нераціонального використання трудових ресурсів не може бути в конкурентоспроможному аграрному виробництві.

Особисті селянські господарства і дрібні селянські, фермерські господарства по суті наполовину наповнюють продовольчі ресурси, що використовують ручний праця i примітивні технології i, не вийшли ще з другого технологічного укладу, не можуть в принципі конкурувати з зарубіжними фермерами.

Вирішенням проблеми 3 підвищення конкурентоспроможності особистих сільських господарств може бути тільки кооперування селян. А це означає створення сільськогосподарських споживчих кооперативів, реально діючих яких всього $60 \%$, але вони тільки на $1 \%$ забезпечують потреби їх учасників. Необхідний широкий розвиток кооперації у всіх іiі формах (кредитна, споживча, закупівельна і постачальницька, логістична, виробнича), що в кінцевому підсумку і може забезпечити підвищення конкурентоспроможності сільськогосподарських виробників. Разом з тим, зростанню 
сільськогосподарської конкуренції може сприяти i інтегрований агробізнес, де в результаті концентрації і централізації капіталу відбувається підвищення ефективності коефіцієнта використання трудових, матеріальних, інноваційних і фінансових ресурсів.

Висновки. Вивчення зарубіжного досвіду формування конкурентного середовища в агропромисловому комплексі дозволяе зробити узагальнюючий висновок: ступінь розвитку конкурентного середовища агропромислового комплексу визначається ефективністю роботи окремих сільськогосподарських підприємств і в дуже більшій мірі державною підтримкою товарного аграрного виробництва за допомогою досить різнобічних, в тому числі і протекціоністських заходів.

\section{СПИСОК ВИКОРИСТАНИХ ДЖЕРЕЛ}

1. Офіційний сайт Державної служби статистики України URL: http:/ /www.ukrstat.gov.ua/ (дата звернення: 30.07.2021)

2. The Global Competiveness Index 2020. The Global Competitiveness Report 2020. World Economic Forum URL: http://reports.weforum.org/global competitiveness report2020/ (дата звернення: 30.07.2021)

3. Зеленська О.О. Агроглобалізація та їі можливі наслідки для України. Економіка АПК. 2012. № 7. С. 128-131.

4. Чинники і тренди економічного зростання в Україні: колективна монографія / за ред. д.е.н М.І.Скрипниченко; НАН України. Київ, 2018. 386 с.

5. Стратегічний план діяльності Міністерства розвитку економіки, торгівлі та сільського господарства України на 2020-2024 роки. URL://me.gov.ua/Documents/ List?lang=uk (дата звернення: 30.07.2021)

\section{REFERENCES}

1. State Statistics Service of Ukraine (2020), available at: http://www.ukrstat.gov.ua/ (Accessed: 30.07.2021).

2. The Global Competiveness Index (2020), The Global Competitiveness Report 2020. World Economic Forum URL: http://reports.weforum.org/global competitiveness report2020/ (Accessed: 30.07.2021)

3. Zelenska O.O. (2012), Ahrohlobalizatsiia ta yii mozhlyvi naslidky dlia Ukrainy. [Agroglobalization and its possible consequences for Ukraine], Ekonomika APK.

4. Scrypnychenko, M.I. (2018), Chynnyky i trendy ekonomichnoho zrostannia v Ukraini [Factors and trends of economic growth in Ukraine], NASU, Kyiv, Ukraine.

5. Ministry of Economic Development, Trade and Agriculture of Ukraine (2020), "Strategic action plan of the Ministry of Economic Development, Trade and Agriculture of Ukraine for 2020-2024", available at: https:/ /me.gov.ua/Documents/List?lang=ukUA\&id= fb0550f06dc2404ab71474a02fb59818\&tag=ProgramiTaPlaniEkonomichnogoISotsialnogo RozvitkuUkraini (Accessed: 30.07.2021)

\section{Кукель Г. С., Братчук У. П., Штефан Л. Б. \\ ПОВЫШЕНИЕ КОНКУРЕНТОСПОСОБНОСТИ АГРАРНОГО ПРОИЗВОДСТВА В УСЛОВИЯХ ГЛОБАЛИЗАЦИИ}

В статье раскрыты сущность и особенности процессов глобализации, отражено влияние этих процессов на развитие отечественного сельского хозяйства. В то же время определены потенциальные и приоритетные направления повышения конкурентоспособности аграрного производства в современных условиях. Освещено 
влияние тенденций на глобальных финансовых и рынках товаров и услуг на стратегию предприятий аграрного сектора. Охарактеризованы современное состояние и условия хозяйствования аграрных предприятий. Определены основные рычаги обеспечения конкурентоспособности аграрного производства. Осуществлен анализ, оценка и диагностика современного состояния и перспектив национального производства сельскохозяйственной продукции в глобализированном мире, обоснованы средства усовершенствования механизмов и стратегий управления конкурентоспособным развитием аграрного сектора, концептуальные основы его государственного регулирования. Раскрыта роль и значение государственной поддержки аграрных предприятий в обеспечении продовольственной безопасности, обеспечении конкурентоспособности и экономической устойчивости аграрных предприятий с учетом их специализации.

Ключевые слова: аграрные предприятия, конкурентоспособность, экономический рост, интеграция, конкурентоспособное развитие, инновации, глобализация, инвестиции.

\section{G. Kukel, U. Bratchuk, L. Shtefan INCREASING THE COMPETITIVENESS OF AGRICULTURAL PRODUCTION IN THE CONTEXT OF GLOBALIZATION}

The article reveals the essence and peculiarities of globalization processes, reflects the influence of these processes on the development of domestic agriculture. At the same time, potential and priority directions for improving the competitiveness of agricultural production in modern conditions have been identified. The impact of trends in global financial and goods and services markets on the strategy of agricultural enterprises was highlighted. The current state and economic conditions of agricultural enterprises are described. The main levers of ensuring the competitiveness of agricultural production have been identified. Analysis, assessment and diagnostics of the current state and prospects of national agricultural production in the globalized world were carried out, the means of improving mechanisms and strategies for managing the competitive development of the agricultural sector and the conceptual basis of its government regulation were justified. The role and importance of state support for agrarian enterprises in ensuring food security, ensuring competitiveness and economic sustainability of agrarian enterprises, taking into account their specialization, is revealed.

Key words: agrarian enterprises, competitiveness, economic growth, integration, competitive development, innovation, globalization, investment. 